\title{
A AMPLIAÇÃO DA COMPETÊNCIA DA JUSTIÇA MILITAR E SUA INCONVENCIONALIDADE: ANÁLISE A PARTIR DA CONVENÇÁO AMERICANA DE DIREITOS HUMANOS
}

\author{
THE EXTENSION OF THE JURISDICTION OF MILITARY JUSTICE AND THEIR \\ INCONVENTIONALITY: ANALYSIS FROM THE AMERICAN CONVENTION ON HUMAN RIGHTS
}

Paula Carolina Araújo da Silva

Pós-graduanda em Direito Médico pelo Centro de Ensino Renata Saraiva Advogada

paula.caroliina@gmail.com

João Thomas Luchsinger

Especialista em Direito Militar Professor Decano na Faculdade de Direito da Universidade Federal do Amazonas Defensor Público Federal

jthomasam@gmail.com

\section{RESUMO}

O presente artigo abordará a alteração da competência da Justiça Militar da União (JMU) em julgar civis, como forma de obstáculo para a obediência aos ditames do Pacto de San José de Costa Rica - Convenção Interamericana de Direitos Humanos. A pesquisa será direcionada às garantias constitucionais do juiz natural, devido ao processo legal e à contradiçáo imposta pela Lei 13.491/17. Dentre elas, destaca-se, pela lesividade, a de não submeter civis à jurisdição militar e, ainda, o direito a ser julgado por um tribunal competente e imparcial. $\mathrm{O}$ artigo conterá análise dos julgados da Corte Interamericana de Direitos Humanos, órgão regional de defesa de direitos humanos, assim como analisará os impactos da ampliação da competência da Justiça Militar.

Palavras-chave: Direitos Humanos. Penal. Garantias. Convencionalidade. Militar. 


\begin{abstract}
This course will address the amendment of the competence of the Military Justice of the Union (JMU) to try civilians as a form of obstacle to compliance with the dictates of the Pact of San José de Costa Rica - Inter-American Convention on Human Rights. The research will be directed to the constitutional guarantees of the natural judge, due to the legal process and the contradiction imposed by Law 13. 491/17. Among them, it is highlighted by the lesivity, that of not subjecting civilians to military jurisdiction, and also, the right to be trial by a competent and impartial tribunal. The monograph will contain jurisprudential analysis of the judgments of the Inter-American Court of Human Rights, a regional human rights body, as well as analyze the impacts of the expansion of the competence of the Military Justice.
\end{abstract}

Keywords: Human rights. Criminal. Guarantees. Conventionality. Military.

Data de submissão: 10/12/2018

Data de aceitação: 13/11/2019

\title{
SUMÁRIO
}

INTRODUÇÃO 1. JUSTIÇA MILITAR DA UNIÁO: PRINCÍPIOS BASILARES E CRIMES MILITARES 1.1. Princípios basilares: hierarquia e disciplina 1.2. Dos crimes militares próprios e impróprios 2. A LEI 13.491/2017 E SUA INCONVENCIONALIDADE COM OS DITAMES DA CONVENÇÃO AMERICANA DE DIREITOS HUMANOS, AFRONTA AO DEVIDO PROCESSO LEGAL 2.1 O controle de convencionalidade na jurisprudência da corte interamericana 2.2 A lei 13.491/2017 e sua (in)compatibilidade com a Convençáo Americana de Direitos Humanos. CONSIDERAÇÓES FINAIS.

\section{INTRODUÇÃO}

O trabalho tem como objeto o estudo dos efeitos ocasionados pela ampliaçáo da competência da Justiça Militar, principalmente no que se refere ao trato com civis, uma vez que estes não se submetem a essa justiça especializada e nem mesmo aos princípios basilares da caserna: hierarquia e disciplina, garantidos, inclusive, na Constituição Federal, no dispositivo 142, caput. O Estatuto dos Militares tenta conceituá-los. ${ }^{1}$

BRASIL. Constituiçáo da República Federativa do Brasil, 1988. 
A problemática gira em torno das garantias constitucionais do juiz natural, devido ao processo legal e à contradição imposta pela Lei $13.491 / 17^{2}$, uma vez que esta não só ampliou a competência militar, mas suprimiu garantias constitucionais reconhecidas internacionalmente. Dentre elas, destaca-se, pela lesividade, a de não submeter civis à jurisdição militar e, ainda, o direito a ser julgado por um tribunal competente e imparcial.

A relevância temática é evidenciada pelo enfoque que a Justiça Militar da União ganhou após a corrida presidencial de 2018, bem como pelo alargamento de crimes militares ser fator preocupante, uma vez que aparenta náo mais definir o crime militar pela lesividade à Administração Militar, mas pelos agentes envolvidos, sejam vítimas ou autores.

O objetivo deste artigo é analisar, sob a ótica internacional, penal e humanitária, a possibilidade da Lei 13.491/17 suprimir direitos fundamentais, assegurados por tratados internacionais dos quais o Brasil seja país membro. $\mathrm{O}$ artigo objetiva, ainda, analisar a possível responsabilização internacional do Estado brasileiro ante a Corte Interamericana de Direitos Humanos.

Para tanto, analisar-se-á, primeiramente, o conceito de crimes militares antes e após a vigência da Lei 13.491/17. Em seguida, analisar-se-á essa inovação legislativa no panorama internacional, fazendo uma contraposição com o controle de convencionalidade, abordando o tema a partir da evolução jurisprudencial da Corte Interamericana de Direitos Humanos. Logo após, as hipóteses serão expostas, criticamente, avaliando-se o que a modificação do art. $9^{\circ}$ do Código Penal Militar implica no ordenamento jurídico interno e se a Lei 13.491/17 é contrária ao disposto na Convenção Americana de Direitos Humanos.

Por fim, acerca das técnicas de investigação, adotou-se o enfoque teórico, com um estudo normativo jurídico, e os enfoques práticos de estudo de casos e da pesquisa-ação. $\mathrm{O}$ estudo normativo jurídico objetivou conhecer os grandes preceitos e princípios informadores do processo penal democrático, demandando um conhecimento sistemático do ordenamento jurídico do país, possibilitando argumentar e sustentar as posiçóes e interpretaçóes propostas.

\section{JUSTIÇA MILITAR DA UNIÁO: PRINCÍPIOS BASILARES E CRIMES MILITARES}

Neste tópico, serão apresentados os princípios de hierarquia e disciplina, os quais estáo como base onde foi fundada a JMU para a compreensão da ingerência destes princípios na vida castrense. Em sequência, será apresentado o conceito de crimes militares antes e após a reforma legislativa, tudo com o fito de avaliar o impacto da alteração para, então, estudar a jurisprudência internacional, o que será feito no tópico 2 .

BRASIL. Lei no 13.491, de 13 de outubro de 2017. 


\subsection{Princípios basilares: hierarquia e disciplina}

A Justiça Militar existe, em nosso ordenamento jurídico, como uma espécie de justiça especializada para processar e julgar crimes militares previstos em lei. A Constituição Federal, do seu art. 122 ao 124, define a competência dos tribunais e juízes militares para processarem e julgarem os crimes militares definidos em lei. ${ }^{3,4}$

Diante disso, tem-se o Decreto-Lei no 1.001, de 21 de outubro de 1969, criando o Código Penal Militar, e ainda o Decreto-Lei no 1.002, de 21 de outubro de 1969, que trouxe à tona o Código de Processo Penal Militar. ${ }^{5,6}$

A forma de organização da Justiça Militar, e mesmo todo o seu trâmite, sempre ficou à margem do resto do ordenamento jurídico, sendo, inclusive, escasso o material acadêmico acerca do assunto. Entretanto, no mês de outubro de 2017, a Justiça Militar teve toda atenção voltada para seu processo penal, quando foi publicada a Lei no $13.491 / 17$, que define a ampliação da competência da JMU.?

Os princípios de hierarquia e disciplina são tidos como os basilares para a Organizaçáo Militar, e não poderia ser de outra forma, pois trata-se de uma organização que tem como principal objetivo a proteção da soberania do Estado. Dito isso, como seria o trato de um batalhão militar, caso não houvesse o poder coercitivo da disciplina e da hierarquia? ${ }^{8}$

Conforme leitura simples do art. 142 da Constituição, ${ }^{9}$ percebe-se que nossa Carta Magna se limitou a citar os dois princípios, sem, no entanto, descrevê-los, o que dificulta o entendimento do que seria a hierarquia e a disciplina para um militar. Para tanto, observa-se:

Art. 142. As Forças Armadas, constituídas pela Marinha, pelo Exército e pela Aeronáutica, são instituiçôes nacionais permanentes e regulares, organizadas com base na hierarquia e na disciplina, sob a autoridade suprema do Presidente da República, e destinam-se à defesa da Pátria, à garantia dos poderes constitucionais e, por iniciativa de qualquer destes, da lei e da ordem (grifo nosso). ${ }^{10}$

Não sendo capaz de descrever o que seriam tais institutos, a vez foi passada ao Estatuto dos Militares. O legislador tentou, mas nem de longe conseguiu esgotar o conceito dos princípios. A Lei 6.880 (Estatuto dos Militares) destina seu Capítulo III para discorrer sobre os institutos mencionados, tratando deles em seu art. 14:

Art. 14. A hierarquia e a disciplina são a base institucional das

\footnotetext{
ARAS, V. As novas competências da Justiça Militar após a Lei 13.491/2017, 2017.

BRASIL. Constituiçáo da República Federativa do Brasil, 1988.

BRASIL. Decreto-lei no 1.001, de 21 de outubro de 1969.

BRASIL. Decreto-lei no 1.002, de 21 de outubro de 1969.

ARAS, V. As novas competências da Justiça Militar após a Lei 13.491/2017, 2017.

NEVES, C. R. C. Manual de Direito Penal Militar, 2012, p. 43.

BRASIL. Constituição da República Federativa do Brasil, 1988.

BRASIL. Constituiçáo da República Federativa do Brasil, 1988.
} 
Forças Armadas. A autoridade e a responsabilidade crescem com o grau hierárquico.

$\$ 1^{\circ}$ A hierarquia militar é a ordenação da autoridade, em níveis diferentes, dentro da estrutura das Forças Armadas. [...]

$\$ 2^{\circ}$ Disciplina é a rigorosa observância e o acatamento integral das leis, regulamentos, normas e disposiçóes que fundamentam o organismo militar [...]

$\$ 3^{\circ}$ A disciplina e o respeito à hierarquia devem ser mantidos em todas as circunstâncias da vida entre militares da ativa, da reserva remunerada e reformado (grifo nosso). ${ }^{11}$

Da leitura do artigo acima é possível perceber que a hierarquia se baseia no poder de autoridade exercido nas jurisdiçôes militares, ou seja, o dever que um militar tem de observar, acatar e respeitar ordens proferidas por seu superior, seja ele imediato ou qualquer outro que tenha patente superior.

Quanto à disciplina, pela leitura do art. 14, percebe-se que está ligada muito mais à obediência e observância do disposto em lei. Aqui é válido ressaltar que seria lei em lato sensu, ou seja, incluídos também os regulamentos disciplinares, portarias e normas feitas pela própria Administração Militar. ${ }^{12}$

Vendo dessa forma, poderia crer-se que tais institutos seriam de bom grado, caso aplicados ao mundo civil, mas a realidade transcende o mero dever formal de obediência e respeito. Tal conclusão deve-se muito ao fato de a serventia à pátria estar intrinsecamente ligada a isolamento, saudade de casa e companheirismo de guerra. Por isso tais princípios são basilares, pois motivam muito mais do que uma mera obediência, mas, sim, um respeito a uma instituição que não só garante a sobrevivência do Estado como também gera uma sensaçáo de pertencimento a algo muito maior. Isso faz com que militares vejam de forma muito mais gravosa o simples fato de uma "resposta atravessada" ou mesmo uma ordem não atendida. ${ }^{13}$

Traçado o núcleo do princípio hierárquico, é natural, para a execução de todo planejamento estratégico de açóes de Forças Armadas, a existência de gestáo coordenada do contingente militar. Quanto à disciplina, Leirner ${ }^{14}$ descreve-a como "irmã siamesa" da hierarquia e, conforme observação de Assis, ${ }^{15}$ é necessário a disciplina espontânea, inspirada no sentimento do dever militar.

Somente no parágrafo acima é perceptível que em nenhum momento falou-se em disciplina cível, ou seja, em nenhum momento foi citada disciplina com afazeres e metas diárias, e sim

11 BRASIL. Lei $\mathbf{n}^{\mathbf{0}} \mathbf{6 . 8 8 0}$, de 9 de dezembro de 1980.

12 BRASIL. Lei no $\mathbf{6 . 8 8 0}$, de 9 de dezembro de 1980.

13 ROTH, R. J. Justiça Militar e as peculiaridades do Juiz Militar na atuaçáo jurisdicional, 2003, p. 24.

14 LEIRNER, P. C. Meia-volta volver: um estudo antropológico sobre a hierarquia militar, 1997, p. 106.

15 ASSIS, J. C. Curso de Direito Disciplinar Militar: da simples transgressão ao processo administrativo, 2012, p. 93-98 
no mais puro sentimento servil, que somente os militares estariam aptos a perceber.

Dito isso, não é necessário alongar nesse tópico, pois a disciplina é vivida de forma singular pelos militares, que a encaram como algo sem a qual não haveria respeito recíproco e sem a qual a Administração Militar perderia totalmente sua essência. O Decreto n ${ }^{\circ}$ 4.346 , de 26 de agosto de $2002,{ }^{16}$ em seus art. $3^{\circ}$ e $4^{\circ}$, faz menção a "princípios gerais do regulamento", que se entende como ponto fundamental de uma acertada acepçáo do que seriam "princípios gerais da disciplina militar". Debrucemo-nos sob a norma:

Art. $3^{\circ}$ - A camaradagem é indispensável à formação e ao convívio da família militar, contribuindo para as melhores relaçóes sociais entre os militares.

$[\ldots]$

Art. $4^{\circ}$ - A civilidade, sendo parte da educação militar, é de interesse vital para a disciplina consciente.

$[\ldots]$

$\$ 2^{\circ}$ - O subordinado é obrigado a todas as provas de respeito e deferência com seus superiores hierárquicos (grifo nosso). ${ }^{17}$

Supracitado, fica cristalino que a disciplina aqui elencada de modo algum pode ser vivenciada ou mesmo entendida no âmbito cível. Dessa forma, sabe-se que, ao confrontar um civil com tal princípio, é impossível precisar que este tenha total consciência da potencial ilicitude de insurgir-se contra uma disciplina que somente pode ser vivenciada em ambiente castrense. Nesse ponto, é interessante citar que sentimentos como a camaradagem e, ainda, a familiaridade, são despertados unicamente pelo "coleguismo de farda" e pela vivência adquirida na caserna. Conforme define Silvestre:

Fato é que a adequação do indivíduo ao fundamental "espírito de corpo" das tropas decorre do exercício da Camaradagem e, o enquadramento daquele perante as normas e as autoridades, da Civilidade. E, analogicamente, os conceitos de Ordem Unida, Camaradagem seria o "alinhamento" e Civilidade, a "cobertura", que permitem, respectivamente, 'marchar ombro a ombro' com o círculo hierárquico e 'enfileirar-se' à 'retaguarda' dos superiores hierárquicos e à frente' dos subordinados, permitindo o fluxo da Estratégia pelas açóes de comandar e/ou obedecer. ${ }^{18}$

Dessa forma, concluindo o presente tópico, parece nítido que, ao primeiro olhar, os princípios sejam simples ordenamentos regulamentares, mas não se pode deixar ludibriar, pois trata-se de algo que transcende os verbos "obedecer" e "servir".

16 BRASIL. Decreto no 4.346, de 26 de agosto de 2002.

17 BRASIL. Decreto no 4.346, de 26 de agosto de 2002.

18 SILVESTRE, L. Ontologia dos Militares: a organização com base na hierarquia e na disciplina, 2016, p. 50. 


\subsection{Dos crimes militares próprios e impróprios}

A Justiça Militar existe, em nosso ordenamento jurídico, como uma espécie de justiça especializada para processar e julgar crimes militares previstos em lei. A Constituição Federal, em seus arts. 122 a 124, define a competência dos tribunais e juízes militares para processar e julgar os crimes militares definidos em lei. Diante disso, tem-se o Decreto-Lei $\mathrm{n}^{\circ}$ 1.001, de 21 de outubro de 1969, criando o Código Penal Militar, e ainda o Decreto -Lei no 1.002, de 21 de outubro de 1969, que trouxe à tona o Código de Processo Penal Militar. ${ }^{19,20,21}$

Dito isso, anteriormente à Lei 13.491/2017 eram definidos, de forma clara, o que seriam crimes militares próprios e impróprios. Quanto aos primeiros, estes seriam os crimes cometidos por militares e que estariam previstos exclusivamente no Código Penal Militar e/ou por ele regulamentados. E os crimes impróprios seriam os que, embora previstos no $\mathrm{CPM}$, também são previstos na legislação penal comum, mas que quando praticados em certas circunstâncias atraem a competência da justiça militar. ${ }^{22}$

Até setembro de 2017, estes crimes estavam dispostos no art. $9^{\circ}$ do Código Penal Militar, sendo prevista a incidência dos crimes militares impróprios no art. 9º, II e suas alíneas. Após a alteração, promovida pela Lei 13.491/2017, a nova redação do art. $9^{\circ}$ apresenta duas grandes alteraçóes. ${ }^{23}$ Para elucidar a questão, apresenta-se um quadro comparativo, para a total compreensâo dos crimes militares, antes e após a lei no $13.491 / 2017$, e as duas principais alteraçôes que o Código Penal Militar sofreu:

19 BRASIL. Constituiçáo da República Federativa do Brasil, 1988.

20 BRASIL. Decreto-lei no 1.001, de 21 de outubro de 1969.

21 BRASIL. Decreto-lei no 1.002, de 21 de outubro de 1969.

22 BRASIL. Lei no 13.491, de 13 de outubro de 2017.

23 BRASIL. Lei no 13.491, de 13 de outubro de 2017. 


\section{Quadro 1 - Quadro comparativo das alteraçóes trazidas pela Lei no $13.491 / 17$ na redaçáo do Art. $9^{\circ}$ do CPM}

\begin{tabular}{|c|c|}
\hline REDAÇÁO ANTERIOR & REDAÇÃO ATUAL \\
\hline $\begin{array}{l}\text { II - Os crimes previstos neste Código, } \\
\text { embora também o sejam com igual } \\
\text { definição na lei penal comum, quando } \\
\text { praticados: }\end{array}$ & $\begin{array}{l}\text { II - Os crimes previstos neste Código e os } \\
\text { previstos na legislaçáo penal, quando praticados: }\end{array}$ \\
\hline $\begin{array}{l}\text { Parágrafo único. Os crimes de que trata } \\
\text { este artigo, quando dolosos contra a } \\
\text { vida e cometidos contra civil, serão da } \\
\text { competência da justiça comum, salvo } \\
\text { quando praticados no contexto de ação } \\
\text { militar realizada na forma do art. } 303 \text { da } \\
\text { Lei no } 7.565 \text {, de } 19 \text { de dezembro de } 1986 \text { - } \\
\text { Código Brasileiro de Aeronáutica. }\end{array}$ & $\begin{array}{l}\$ 1^{\circ} \text { Os crimes de que trata este artigo, quando } \\
\text { dolosos contra a vida e cometidos por militares } \\
\text { contra civil, serão da competência do Tribunal } \\
\text { do Júri. } \\
\$ 2^{\circ} \text { Os crimes de que trata este artigo, quando } \\
\text { dolosos contra a vida e cometidos por militares } \\
\text { das Forças Armadas contra civil, serão da } \\
\text { competência da Justiça Militar da União, se } \\
\text { praticados no contexto: I - do cumprimento } \\
\text { de atribuiçóes que lhes forem estabelecidas } \\
\text { pelo Presidente da República ou pelo Ministro } \\
\text { de Estado da Defesa; II - de açáo que envolva } \\
\text { a segurança de instituição militar ou de missão } \\
\text { militar, mesmo que não beligerante; ou III - de } \\
\text { atividade de natureza militar, de operaçáo de paz, } \\
\text { de garantia da lei e da ordem ou de atribuiçáo } \\
\text { subsidiária, realizadas em conformidade com o } \\
\text { disposto no art. } 142 \text { da Constituição Federal e } \\
\text { na forma dos seguintes diplomas legais: a) Lei } \\
\text { no } 7.565 \text {, de } 19 \text { de dezembro de } 1986 \text { - Código } \\
\text { Brasileiro de Aeronáutica; b) Lei Complementar } \\
\text { no } 97 \text {, de } 9 \text { de junho de } 1999 \text {; c) Decreto-Lei no } \\
1.002 \text {, de } 21 \text { de outubro de } 1969 \text { - Código de } \\
\text { Processo Penal Militar; e d) Lei no } 4.737 \text {, de } 15 \\
\text { de julho de } 1965 \text { - Código Eleitoral. }\end{array}$ \\
\hline $\begin{array}{l}\text { CRIMES EXTRAVAGANTEMENTE } \\
\text { MILITARES }\end{array}$ & $\begin{array}{l}\text { a) Todos os crimes previstos na Decreto-Lei no } \\
2.848 \text {, de } 07 \text { de dezembro de } 1940^{24} \text {; } \\
\text { b) Todos os crimes previstos em TODA a } \\
\text { legislaçáo penal especial vigente. }\end{array}$ \\
\hline
\end{tabular}

Fonte: elaborada pela autora, com base na lei $\mathrm{n}^{\mathrm{o}} 13.491 / 17 . .^{25}$

Ante o corroborado, é perceptível que, após a ampliação da competência da JMU, qualquer crime previsto, tanto no Código Penal Militar como no Código Penal Brasileiro, pode ser considerado militar, desde que cometido dentro dos parâmetros dispostos nas

24 BRASIL. Decreto-Lei no 2.848, de 07 de dezembro de 1940.

25 BRASIL. Lei $\mathbf{n}^{\mathbf{0}} \mathbf{1 3 . 4 9 1}$, de 13 de outubro de 2017. 
alíneas dos incisos II e III, do art. 9º do CPM. Mas, qual a real problemática de tudo isso? Simplória e preocupante é a resposta: o núcleo do problema está nos tipos penais abertos, que foram criados com a nova legislação militar, pois depreende-se da leitura que qualquer crime do Código Penal Brasileiro - CPB pode ser objeto de julgamento militar. Para isso, basta ser o agente militar ou as condiçóes do crime afetarem a "administração militar" ${ }^{26}$

Entretanto, apresentam-se algumas questôes: como um crime de infanticídio, aborto (conduta, erroneamente, ainda criminalizada) ou ainda incitação ao suicídio pode afetar a Administração Militar (é válido ressaltar que tais crimes podem ser considerados militares, mesmo que praticados fora de circunscriçáo militar)? Qual a finalidade da JMU? O Direito Penal não seria a ultima ratio? Para tanto, deve-se analisar a finalidade do Direito Militar.

De acordo com Neves, o Direito Militar está como um conjunto de normas jurídicas, as quais têm como objeto a determinaçáo de sançóes penais e suas medidas coercitivas, que atinjam os bens jurídicos protegidos pelas Forças Militares. O autor cita, inclusive, que, quanto aos bens jurídicos protegidos pelo Direito Militar, incluem-se, entre outros, a hierarquia e a disciplina. ${ }^{27}$

Seja qual for o bem jurídico tutelado, este sempre terá uma relação direta com o funcionamento e respeito às instituições militares. Ou seja, ainda que tutelado pelo Direito Comum, caso agrida a instituição militar, a competência será atraída para a JMU, sendo necessária uma análise profunda.

Em se tratando de uma justiça especializada, o caminho é o desaparecimento da referida justiça. A Corte Interamericana de Direitos Humanos já se pronunciou, no sentido de que a Justiça Militar deve ser mantida a militares da ativa e deve ter seu funcionamento reduzido em tempos de paz. Deliberou, ainda, que sua funcionalidade somente deve ser aceita, em totalidade, em tempos de guerra. Melhor dizendo, em tempos de paz deve-se restringir a JMU ao simples funcionamento daqueles órgãos que sejam indispensáveis à salvaguarda da soberania nacional. A não observância de tais componentes gera consequências no âmbito internacional, que serão dissertadas no próximo tópico do presente trabalho. ${ }^{28}$

\section{A LEI No 13.491/2017 E SUA INCONVENCIONALIDADE COM OS DITAMES DA CONVENÇÁO AMERICANA DE DIREITOS HUMANOS, AFRONTA AO DEVIDO PROCESSO LEGAL}

Neste tópico, o objetivo é fazer uma análise da legislação interna, qual seja, da Lei 13.491/17, com os ditames internacionais de garantia de direitos humanos. De modo mais particular, examina-se o Sistema Interamericano de Direitos Humanos, o sistema regional do qual o Brasil é sujeito. Para tanto, analisa-se o "controle de convencionalidade",

26 BRASIL. Lei no 13.491, de 13 de outubro de 2017.

27 NEVES, C. R. C. Manual de Direito Penal Militar, 2012, p. 43.

28 CtIDH. Caso Almonacid Arellano y otros Vs. Chile, de 26 de setembro de 2006. 
através da jurisprudência da Corte, e também se realiza uma análise comparativa da Lei $13.491 / 17$ com os artigos da CADH. ${ }^{29}$

\subsection{O controle de convencionalidade na jurisprudência da Corte Interamericana}

O Sistema Interamericano de Direitos Humanos tem, como órgãos principais, a Corte Interamericana de Direitos Humanos e a Comissão Interamericana. A Corte Interamericana de Direitos Humanos (Corte IDH) é uma instituição judicial autônoma do sistema interamericano, que tem como objetivo aplicar e interpretar a Convenção Americana sobre Direitos Humanos (CADH), podendo, também, no exercício da sua competência consultiva, expandir a atividade interpretativa para outros tratados concernentes à proteção dos direitos humanos nos estados americanos. ${ }^{30}$

A Emenda Constitucional 45/04 acrescentou o $\$ 3^{\circ}$ do art. $5^{\circ}$ da CRFB e trouxe a possibilidade de os tratados internacionais de direitos humanos serem aprovados por um quórum qualificado, a fim de que os referidos tratados sejam material e formalmente constitucionais e assim recebam o status de "emendas constitucionais". ${ }^{31}$

O controle de convencionalidade foi apresentado como uma forma de aferir a compatibilidade de uma norma interna com norma internacional firmada pela CADH. O conceito do instituto tem se dado como uma construção da Corte IDH, com o fim de garantir a proteção internacional dos direitos humanos e, principalmente, o cumprimento de suas sentenças pelos estados membros. ${ }^{32}$

Para Rey ${ }^{33}$, o controle de convencionalidade deve ser definido como uma instituição, que é utilizada para aplicar o Direito Internacional e, especificamente, a Convençâo Americana. De acordo com Mazzuoli, o controle de convencionalidade se dá com a (in)compatibilidade legislativa com os tratados de direitos humanos (formalmente constitucionais ou não) em vigor no país. ${ }^{34}$

A Corte Interamericana, desde o início de suas atividades, presta-se ao papel de fiscalizar a adequação das leis dos países-membros com seus tratados, entretanto somente em 2006 surgiu o termo "controle de convencionalidade", com o caso Almonacid Arellano y otros vs Chile. ${ }^{35}$

No presente caso, a CtIDH entendeu que o controle de convencionalidade não é um instrumento a ser utilizado pelo tribunal internacional, mas que podem, também, os juízes e tribunais internos, realizar o exame de compatibilidade das leis domésticas com a Convenção Americana, levando em conta não só a legislação seca da Convenção, mas

$29 \quad$ BRASIL. Lei $\mathbf{n}^{\mathbf{0}} \mathbf{1 3 . 4 9 1}$, de 13 de outubro de 2017.

30 CtIDH. Relatório Anual da Corte Interamericana de Direitos Humanos, 2018.

31 BRASIL. Emenda Constitucional no 45, de 30 de dezembro de 2004.

32 MAZZUOLI, V. O. O controle jurisdicional da convencionalidade das leis, 2013, p. 40.

33 REY, S. A. Manual de Derecho Internacional de Los Derechos Humanos: Parte General, 2016, p. 167.

34 MAZZUOLI, V. O. O controle jurisdicional da convencionalidade das leis, 2013, p. 45.

35 CtIDH. Caso Almonacid Arellano y otros Vs. Chile, de 26 de setembro de 2006. 
também observando qual a interpretação da Corte sobre o assunto.

Além da base principiológica, os arts. 1.1 e 2 da CADH asseveram, respectivamente, as obrigaçóes negativas e positivas do Estado. Compreendendo a negativa, no dever de respeitar os direitos e liberdades garantidos pelos instrumentos de direitos humanos, e a positiva - a que é o foco da questão - que é o dever de adequar o direito interno às normas da Convenção e de criar normas/mecanismos que assegurem direitos que ainda não estejam materialmente garantidos:

Artigo 1. Obrigação de respeitar os direitos

1. Os Estados Partes nesta Convençáo comprometem-se a respeitar os direitos e liberdades nela reconhecidos e a garantir seu livre e pleno exercício a toda pessoa que esteja sujeita à sua jurisdiçáo, sem discriminaçáo alguma por motivo de raça, cor, sexo, idioma, religiáo, opiniōes políticas ou de qualquer outra natureza, origem nacional ou social, posição econômica, nascimento ou qualquer outra condição social.

\section{Artigo 2. Dever de adotar disposiçóes de direito interno}

Se o exercício dos direitos e liberdades mencionados no artigo 1 ainda não estiver garantido por disposiçóes legislativas ou de outra natureza, os Estados Partes comprometem-se a adotar, de acordo com as suas normas constitucionais e com as disposiçóes desta Convençáo, as medidas legislativas ou de outra natureza que forem necessárias para tornar efetivos tais direitos e liberdades (grifo nosso). ${ }^{36}$

No art. 2, é possível observar que o controle de convencionalidade sempre esteve implícito na CADH e explica toda a hipótese desse projeto, uma vez que o Estado brasileiro se contrapóe totalmente ao pactuado no Direito Internacional.

Outro ponto importante foi definido no caso Almonacid Arellano vs Chile, em que a Corte definiu que os juízes e tribunais internos apresentam a obrigação de procederem o exame de compatibilidade das leis domésticas com a Convenção ex officio, ou seja, sem que haja provocaçáo das partes, o que pode ser denominado como controle difuso de convencionalidade. ${ }^{37}$

Logo, o controle de convencionalidade possui dois aspectos: o controle que deve ser feito ainda na jurisdição interna, como o controle de concentrado, aquele feito pela Corte $\mathrm{IDH}$; e o que levanta a questáo que, caso observado o controle interno, o estado membro não seja levado a julgamento pela Corte, visto o princípio da subsidiariedade da Corte Interamericana (art. 47, item "b", CADH). ${ }^{38}$

No caso Gómez Palomino vs. Peru, a Corte definiu que qualquer tratado de direitos humanos é paradigma para o controle de convencionalidade e não somente a Convenção.

36 CADH. Pacto de Sáo José da Costa Rica, de 22 de novembro de 1969.

37 CtIDH. Caso Almonacid Arellano y otros Vs. Chile, de 26 de setembro de 2006.

38 CADH. Regulamento da Comissáo Interamericana de Direitos Humanos, 2009. 
No caso citado, a Corte, pela primeira vez, fez controle de convencionalidade pela Convenção Interamericana sobre Desaparecimento Forçado de Pessoas. ${ }^{39}$ Mazzuoli definiu os tratados de direitos humanos como "bloco de convencionalidade", pois os direitos previstos nesses tratados formam um corpus juris de direitos humanos, que devem ser observados pelos Estados. ${ }^{40}$

Sendo assim, apesar de escritores como Sagués ${ }^{41}$, que define o controle como uma ferramenta que pode trazer sérias restriçóes à soberania do Estado, citando, inclusive, Jean Bodin $^{42}$ e reforçando a ideia de um poder absoluto, fica claro que a competência da CtIDH somente é atraída após todo o trâmite interno do Estado ser ineficaz na garantia de direitos humanos.

A jurisprudência da Corte seguiu amadurecendo o conceito de controle e, em casos como La Cantuta vs Perít ${ }^{43}$ Boyce y outros vs Barbados ${ }^{44}$ e Trabajadores Cesados del Congreso vs Perú, ${ }^{45}$ ela adicionou o seguinte:

Quando um Estado ratifica um tratado internacional como a Convençấo Americana, seus juízes estão sujeitos a ele, o que obriga-o a assegurar que o efeito útil da Convençấo não seja diminuído ou anulado pela aplicação de leis contrárias às suas disposiçōes; e fim. Em outras palavras, os órgáos do Poder Judiciário devem exercer não apenas um controle de constitucionalidade, mas também de convencionalidade, ex officio, entre as normas internas e a Convençáo Americana, evidentemente no âmbito de suas respetivas competências e dos respectivos regulamentos processuais. Esta função não deve ser limitada exclusivamente pelas declaraçôes ou atos dos acionantes em cada caso concreto, ainda que náo implique que este controle deva ser sempre exercido, sem considerar outras hipóteses formais e materiais de admissibilidade e origem deste tipo de açôes (tradução livre) (grifo nosso). ${ }^{46}$

Conforme o destacado, a Corte buscou não interferir no protagonismo do Estado, con-

39 CtIDH. Caso Gómez Palomino vs. Peru, de 22 de novembro de 2005.

40 MAZZUOLI, V. O. O controle jurisdicional da convencionalidade das leis, 2013, p. 100.

41 SAGUÉS, N. P. Obligaciones internacionales y control de convencionalidade, 2011, p. 118.

42 SAGUÉS, N. P. Obligaciones internacionales y control de convencionalidade, 2011, p. 119.

43 CtIDH. Caso La Cantuta Vs. Perú, de 29 de novembro de 2006.

44 CtIDH. Caso Boyce y outros vs Barbados, de 2 de novembro de 2007.

45 CtIDH. Caso Trabajadores Cesados del Congreso vs Peru, de 24 de novembro de 2006.

46 Texto Original: "Cuando un Estado ha ratificado un tratado internacional como la Convención Americana, sus jueces están sometidos a ella, lo que les obliga a velar porque el efecto útil de la Convención no se vea mermado o anulado por la aplicación de leyes contrarias a sus disposiciones, objeto y fin. En otras palabras, los órganos del Poder Judicial deben ejercer no sólo un control de constitucionalidad, sino también de convencionalidad, ex officio, entre las normas internas y la Convención Americana, evidentemente en el marco de sus respectivas competencias y de las regulaciones procesal espertinentes. Esta función no debe quedar limitada exclusivamente por las manifestaciones o actos de los accionantes en cada caso concreto, aunque tampoco implica que ese control deba ejercerse siempre, sin considerar otros supuestos formales y materiales de admisibilidad y procedencia de este tipo de acciones". 
ferindo o poder de fazer o controle de convencionalidade internamente, evitando, assim, que a Corte seja acionada, resolvendo internamente a questão. Nessa mesma linha, no caso Liakat Ali Alibux vs Suriname ${ }^{47}$, é assinalado que a Convenção Americana não impóe um protocolo específico para realizar o controle de convencionalidade, ou seja, mais importante que a formalidade do ato é a eficácia material do controle e ainda os órgãos que resolvem a controvérsia de forma interna. ${ }^{48}$

Supracitado, o aparato jurisprudencial da Corte apresenta conceito constante e que tem sua evolução voltada apenas para que possa ser flexibilizado o controle de convencionalidade, para que todo juiz e tribunal possa fazê-lo de forma eficaz. Um exemplo de controle de convencionalidade feito pelo Brasil foi no caso do crime de desacato, previsto no art. 331 do Código Penal Brasileiro, em que o Superior Tribunal de Justiça, através de sua quinta turma, decidiu pela inconvencionalidade do crime de desacato:

DIREITO PENAL E PROCESSUAL PENAL. RECURSO ESPECIAL. ROUBO, DESACATO E RESISTÊNCIA. APELAÇÃO CRIMINAL. EFEITO DEVOLUTIVO AMPLO. SUPRESSÃO DE INSTÂNCIA. NÁO OCORRÊNCIA. ROUBO. PRINCÍPIO DA INSIGNIFICÂNCIA. INAPLICABILIDADE. DESCLASSIFICAÇÃO DO CRIME DE ROUBO PARA O DE CONSTRANGIMENTO ILEGAL. AUSÊNCIA DE FUNDAMENTAÇÃO. SÚMULA 284/STF. TEMA NÁO PREQUESTIONADO. SÚMULAS 282 E 356 DO STF. DESACATO. INCOMPATIBILIDADE DO TIPO PENAL COM A CONVENÇÃO AMERICANA DE DIREITOS HUMANOS. CONTROLE DE CONVENCIONALIDADE. [...] 6. Decidiu-se, no precedente repetitivo, que, "no plano material, as regras provindas da Convenção Americana de Direitos Humanos, em relaçáo às normas internas, sáo ampliativas do exercício do direito fundamental à liberdade, razáo pela qual paralisam a eficácia normativa da regra interna em sentido contrário, haja vista que náo se trata aqui de revogaçáo, mas de invalidade." [...] 11. A adesáo ao Pacto de Sáo José significa a transposiçáo, para a ordem jurídica interna, de critérios recíprocos de interpretaçáo, sob pena de negaçáo da universalidade dos valores insertos nos direitos fundamentais internacionalmente reconhecidos. Assim, o método hermenêutico mais adequado à concretizaçáo da liberdade de expressáo reside no postulado pro homine, composto de dois princípios de proteçáo de direitos: a dignidade da pessoa humana e a prevalência dos direitos humanos [...] (grifo nosso). ${ }^{49}$

No mesmo julgado, destaca-se:

[...] 14. Punir o uso de linguagem e atitudes ofensivas contra agentes estatais é medida capaz de fazer com que as pessoas se abstenham de usufruir do direito à liberdade de expressão, por temor de sançóes penais, sendo esta uma das razóes pelas quais a CIDH estabeleceu

47 CtIDH. Caso Liakat Ali Alibux vs Suriname, de 30 de janeiro de 2014.

48 MAZZUOLI, V. O. O controle jurisdicional da convencionalidade das leis, 2013, p. 98.

49 BRASIL. Superior Tribunal de Justiça. Recurso Especial no 2016/0032106-0 SP, 2016. 
a recomendaçáo de que os países aderentes ao Pacto de Sáo Paulo abolissem suas respectivas leis de desacato [...] (grifo nosso). ${ }^{50}$

Além do descrito, tem-se o seguinte julgado, da Terceira Turma do STJ, que tempos depois decidiu contrário ao disposto pela Quinta Turma, definindo que as decisóes da CtIDH têm caráter meramente consultivo, não obrigatório e, para tanto, a decisão expressa o protagonismo dos estados membros quando exercem o controle difuso de convencionalidade, sendo destes a soberania:

HABEAS CORPUS. RECEBIMENTO DA DENÚNCIA. VIOLAÇÃO DO ART. 306 DO CÓDIGO DE TRÂNSITO E DOS ARTSS. 330 E 331 DO CÓDIGO PENAL. PRINCÍPIO DA CONSUNÇÃO. IMPOSSIBILIDADE. MANUTENÇÃO DA TIPIFICAÇẨO DO CRIME DE DESACATO NO OR̉DENAMENTO JURÍDICO. DIREITOS HUMANOS. PACTO DE SÃO JOSÉ DA COSTA RICA (PSJCR). DIREITO À LIBERDADE DE EXPRESSÃO QUE NÃO SE REVELA ABSOLUTO. CONTROLE DE CONVENCIONALIDADE. INEXISTÊNCIA DE DECISÃO PROFERIDA PELA CORTE (IDH). ATOS EXPEDIDOS PELA COMISSÃO INTERAMERICANA DE DIREITOS HUMANOS (CIDH). AUSÊNCIA DE FORÇA VINCULANTE. TESTE TRIPARTITE. VETORES DE HERMENEUTICA DOS DIREITOS TUTELADOS NA CONVENÇÃO AMERICANA DE DIREITOS HUMANOS. POSSIBILIDADE DE RESTRIÇÃO. PREENCHIMENTO DAS CONDIÇÓES ANTEVISTAS NO ART. 13.2. DO PSJCR. SOBERANIA DO ESTADO. TEORIA DA MARGEM DE APRECIAÇÃO NACIONAL (MARGIN OF APPRECIATION). INCOLUMIDADE DO CRIME DE DESACATO PELO ORDENAMENTO JURÍDICO PÁTRIO, NOS TERMOS EM QUE ENTALHADO NO ART. 331 DO CÓDIGO PENAL. INAPLICABILIDADE, IN CASU, DO PRINCÍPIO DA CONSUNÇÃO TÃO LOGO QUANDO DO RECEBIMENTO DA DENÚNCIA. WRIT NÃO CONHECIDO.

[... 12. A CIDH e a Corte Interamericana têm perfilhado o entendimento de que o exercício dos direitos humanos deve ser feito em respeito aos demais direitos, de modo que, no processo de harmonização, o Estado desempenha um papel crucial mediante o estabelecimento das responsabilidades ulteriores necessárias para alcançar tal equilíbrio exercendo o juízo de entre a liberdade de expressão manifestada e o direito eventualmente em conflito. 13. Controle de convencionalidade, que, na espécie, revela-se difuso, tendo por finalidade, de acordo com a doutrina, "compatibilizar verticalmente as normas domésticas (as espécies de leis, lato sensu, vigentes no país) com os tratados internacionais de direitos humanos ratificados pelo Estado e em vigor no território nacional.” 14. Para que a produçáo normativa doméstica possa ter validade e, por conseguinte, eficácia, exige-se uma dupla compatibilidade verti-

$50 \quad$ BRASIL. Lei no $\mathbf{1 3 . 4 9 1}$, de 13 de outubro de 2017. 
cal material. 15. Ainda que existisse decisão da Corte (IDH) sobre a preservação dos direitos humanos, essa circunstância, por si só, não seria suficiente a elidir a deliberação do Brasil acerca da aplicação de eventual julgado no seu âmbito doméstico, tudo isso por força da soberania que é inerente ao Estado. Aplicação da Teoria da Margem de Apreciação Nacional (margin of appreciation). 16. O desacato é especial forma de injúria, caracterizado como uma ofensa à honra e ao prestígio dos órgãos que integram a Administração Pública. Apontamentos da doutrina alienígena [...] (grifo nosso). ${ }^{51}$

A inconstância do STJ força o STF a manifestar-se sobre o tema, momento que se espera a padronização da jurisprudência. Entretanto, a nível acadêmico, as decisóes acima expostas evidenciam os obstáculos encontrados para a efetivaçáo, não somente dos direitos humanos, mas também das sentenças e instruções da Corte Interamericana, sendo encontrados ainda mais obstáculos para o exame de compatibilidade de leis já existentes.

\subsection{A lei 13.491/2017 e sua (in)compatibilidade com a Convenção Americana de Direitos Humanos}

O ponto crucial da Lei 13.491 está ligado ao devido processo legal, mais precisamente ao juiz natural para julgamento de crimes militares. Sendo assim, superada a análise dos arts. 1.1 e 2 do instrumento, o art. $8^{\circ}$ será desmembrado, para que possam ser estudadas suas particularidades em contraponto à Lei 13.491 .

$\mathrm{O}$ art. $8^{\circ} \mathrm{da} \mathrm{CADH}$ cita que todo acusado tem o direito de ser processado e julgado por um tribunal competente, independente e imparcial. ${ }^{52}$ Gomes assinala que todas as garantias abarcadas pelo artigo $8^{\circ}$ da Convenção fazem parte do princípio do devido processo legal. Cada item do artigo reflete uma garantia que está pacificada. ${ }^{53}$ Diante da alteração legislativa acontecer na competência das cortes militares para julgamento de civis, este tópico se aterá ao $8^{\circ}$, item 1 da CADH:

\footnotetext{
Artigo 8. Garantias judiciais

1.Toda pessoa tem direito a ser ouvida, com as devidas garantias e dentro de um prazo razoável, por um juiz ou tribunal competente, independente e imparcial, estabelecido anteriormente por lei, na apuração de qualquer acusação penal formulada contra ela, ou para que se determinem seus direitos ou obrigaçóes de natureza civil, trabalhista, fiscal ou de qualquer outra natureza (grifo nosso). ${ }^{54}$
}

O item traz, em seu bojo, dois ditames do devido processo legal: a) prazo razoável; b) juiz natural. O prazo razoável diz respeito à celeridade processual, ou seja, o Estado deve

$51 \quad$ BRASIL. Superior Tribunal de Justiça. Habeas Corpus no 379.269 Mato Grosso do Sul, 2017.

52 CADH. Pacto de Sáo José da Costa Rica, de 22 de novembro de 1969.

53 GOMES, L. F. Comentários à Convençáo Americana sobre Direitos Humanos: pacto de San José da Costa Rica, 2013, p. 31.

54 CADH. Pacto de Sáo José da Costa Rica, de 22 de novembro de 1969. 
proporcionar os meios cabíveis e possíveis para que o processo se resolva de forma rápida e eficaz, sendo este ponto analisado sempre em consonância com as peculiaridades do caso concreto. A Corte suscitou tais pontos no caso La Cantuta vs Perú. ${ }^{55}$

Quanto ao juiz competente, este trata do princípio do juiz natural, que consiste em juiz ou tribunal, previamente definidos, que julgarão o caso na medida de sua jurisdição. Assim, a violação ao princípio do juiz natural macula todo o processo, pois, a partir da inobservância, ainda que todo o processo siga seu curso, este já estará nulo. A figura do juiz natural tornou-se um dos pontos mais batidos pela Corte, visto todas as ditaduras que a América Latina já vivenciou e sendo de suma importância a definição do julgador, para, depois, aferir a violação. O Brasil reconhece tal princípio, no art. 5º, LIII da Constituição Federal..$^{56}$

Apesar de não expresso no art. 8.1 e de a Constituição somente fazer menção à proibição de tribunais de exceção, o paradigma da questáo está na jurisprudência da Corte, quando esta define que civis não devem ser submetidos a tribunais militares.

Em Palamara Iribarne vs Chile ${ }^{57}$, a Corte delimitou a competência da jurisdição penal militar restritiva à proteção de interesses jurídicos especiais vinculados às funçóes que a lei atribui às forças militares, motivo pelo qual só se pode julgar militares pela prática de crimes e faltas que, por sua própria natureza, atentem contra bens jurídicos próprios de ordem militar.

Contrário a isso, a previsão legal de civis serem submetidos às Cortes militares encontrase no art. 9o do Código Penal Militar (doravante CPM): "art. 90 Consideram-se crimes militares, em tempo de paz: [...] III- os crimes praticados por militar da reserva, ou reformado, ou por civil, contra as instituiçóes militares" (grifo nosso). ${ }^{58} \mathrm{O}$ entendimento do Superior Tribunal Militar é que deve ser observada a intençáo do agente civil, para definir se o crime terá natureza comum ou será considerado militar. Em caso de afronta à instituição militar, o crime será dirigido para a justiça especializada.

Apesar de, primeiramente, não ser visível o problema de levar um civil a uma Corte militar, é necessário avaliar que existem princípios basilares para o devido processo legal; novamente, o princípio do juiz natural. A prerrogativa que define por qual juízo um indivíduo será processado é a natureza da ação e, ainda, a posição do agente. É possível analisar pelo art. $9^{\circ}$ do CPM que o requisito para ser submetido à Corte militar é ser o indivíduo militar.

Atenção neste ponto para o caso Arguelles y otros vs. Argentina ${ }^{59}$, em que a Corte assinala:

A Corte estabeleceu que, em um Estado democrático de direito, tal jurisdiçáo [militar] deve ser restritiva e expedita de uma maneira que se aplique somente à proteção de direitos jurídicos especiais, de caráter militar, e que tenham sido violados por membros das forças armadas. Militares no exercício de suas funçōes. (tradução

55 CtIDH. Caso La Cantuta Vs. Perú, de 29 de novembro de 2006.

56 BRASIL. Constituiçáo da República Federativa do Brasil, 1988.

57 CtIDH. Caso Palamara Iribarne Vs. Chile, de 22 de novembro de 2005.

58 BRASIL. Decreto-lei no $\mathbf{1 . 0 0 1}$, de 21 de outubro de 1969.

59 CtIDH. Caso Argüelles y otros Vs. Argentina, de 20 de novembro de 2014. 
livre, $\mathrm{CtIDH}, 2014){ }^{60}$

Em contrapartida a isso, tem-se a ampliação da competência da Justiça Militar, mesmo após anos de jurisprudência da Corte Interamericana em sentido contrário. O ordenamento brasileiro resolveu ignorar o Pacto de San José da Costa Rica (1969) e aplicar tal legislação sem efetuar o controle de convencionalidade.

Nesse ponto, existe também uma afronta aos princípios de boa-fé e pacta sunt servanda, os quais regem os tratados internacionais. Ou seja, quando o estado membro assina determinado tratado, está automaticamente submetendo-se aos ditames daquele instrumento e, principalmente, comprometendo-se a não adotar direito interno que o contrarie.

Com a lei 13.491/17, o Brasil adotou uma política de presença permanente da Justiça Militar da União, mantendo seu funcionamento e, principalmente, julgamentos de civis e militares em tempo de paz, o que, mais uma vez, vai contra o que é asseverado na jurisprudência da Corte. Em síntese, no Caso Cesti Hurtado vs Perú, ${ }^{61}$ a CtIDH define que, caso o Estado julgue necessária a existência de uma jurisdição penal militar, esta deve limitar-se ao julgamento de crimes de função, cometidos por militares em serviço ativo; entendendo, portanto, que em nenhuma circunstância um civil pode ser julgado pelos tribunais militares, ainda que se trate de militar aposentado. ${ }^{62,63}$

Não se trata de uma questão apenas de julgar civis, mas sim da insegurança jurídica e, ainda, de submeter civis a parâmetros militares que os mesmos desconhecem. Sobre o assunto, novamente, o Palamara Iribarne vs. Chile ${ }^{64}$ assevera que a jurisdição militar, em um Estado Democrático de Direito, em tempos de paz, deve ser reduzida e, se possível, desaparecer. Mas, caso o Estado a conserve, deve ser em seu mínimo e fundada em princípios e garantias de Direito Penal moderno.

Fazendo um rápido controle de convencionalidade com a dinâmica exposta, o art. $9^{\circ}$ do Código Penal Militar, quando traz em seus incisos a previsão de julgamento de civis e militares (ativos ou inativos), viola o art. $8.1 \mathrm{da} \mathrm{CADH}$, pois não observa o devido processo legal quando atrai a jurisdição militar para matérias que não afetam diretamente a administração militar, ultrapassando seu caráter restritivo e excepcional.

Frisa-se que a mera existência de tribunais militares não fere a Convenção. $\mathrm{O}$ instrumento só é violado a partir da submissão de civis a juízo militar. A Corte citou a permanência de tribunais militares e sua manutenção no Caso Durand y Ugart vs Perú. ${ }^{65}$

\footnotetext{
Texto Original: "La Corte ha estabelecido que em um Estado democrático de Derecho, dicha jurisdicción [militar] ha de ser restrictiva y expepcional de manera que se aplique únicamente em la protección de bienes jurídicos especiales, de caráter castrense, y qye hayan sido vulnerados por miembros de las fuerzas militares en el ejercicio de sus funciones".

Corte IDH. Caso Cesti Hurtado Vs. Perú, de 29 de setembro de 1999.

2015, p. 208.

PAIVA, C.; HEEMANN, T. A. Jurisprudência internacional de direitos humano,

$63 \quad$ BRASIL. Lei $\mathbf{n}^{0}$ 13.491, de 13 de outubro de 2017.

64 CtIDH. Caso Palamara Iribarne Vs. Chile, de 22 de novembro de 2005.

65 CtIDH. Caso Durand y Ugarte Vs. Perú,16 de agosto de 2000.
} 
Além da questão de competência, tem-se, também, a imparcialidade do juiz, que é justamente ser um terceiro que não tem interesse nenhum no resultado útil do processo com o julgador. Colocando-se um juiz militar para julgamento de civis em tempo de paz, não é possível vislumbrar a imparcialidade deste, visto que, não raro, o responsável pelo inquérito policial militar é o próprio "ofendido", ou então é um superior hierárquico imediato, com interesse de ver-se respeitado ante a tropa.

Logo, ao colocar-se um juiz militar, ou melhor, um colegiado militar, para julgar um civil, não existe imparcialidade material, pois todos ali têm o interesse de submeter o civil aos ordenamentos militares. Ressalta-se que a imparcialidade, ou qualquer outro mecanismo do devido processo legal, deve ser ofertada de forma material. Ou seja, o Estado náo deve somente prever legislativamente aquele mecanismo, deve, também, fornecer os meios necessários para que aquela garantia seja assegurada de forma válida e não meramente ilusória.

Tendo em vista que os julgamentos em Cortes militares, na maioria das vezes, têm o Direito Penal ditado pelo julgador e não pelo Código e que, ainda que todo o processo corra dentro da regularidade, com o desvio de competência errôneo trazido pela Lei 13.491/17, pode-se afirmar que o Brasil está sujeito a novas condenaçóes internacionais. Uma vez que a CtIDH possui sólido aparato jurisprudencial, em sentido totalmente diverso do que a Lei propóe, ainda é mais temeroso quando se lembra que o Brasil já foi condenado pela Corte em quatro oportunidades, sendo uma delas no caso Gomes Lund vs. Brasil (Guerritha do Araguaia), pelas atrocidades cometidas no regime de ditadura militar e ainda pela inércia estatal em punir os máximos responsáveis. ${ }^{66,67}$

Ante o exposto, fica evidente que a alteração legislativa traz um protagonismo indesejado para a Justiça Militar, visto que a justiça especializada deveria ser organizada e estruturada, para que se restrinja unicamente a militares ativos nas Forças Armadas.

\section{CONSIDERAÇÓES FINAIS}

A proposta do artigo foi verificar se a modificaçáo legislativa, ocorrida em outubro do ano de 2017, para ampliar a competência da JMU, viola ou não princípios constitucionais, em especial o do juiz natural e o do devido processo legal, e também se suprimiu garantias constitucionais reconhecidas internacionalmente.

O objetivo foi analisar, sob a ótica internacional, penal e humanitária, a possibilidade de a Lei 13.491/17 suprimir direitos fundamentais, assegurados por tratados internacionais dos quais o Brasil seja estado membro. E, ainda, a possível responsabilizaçáo internacional do Estado brasileiro ante a Corte Interamericana de Direitos Humanos.

\footnotetext{
66 $\quad$ BRASIL. Lei $\mathbf{n}^{\mathbf{0}} \mathbf{1 3 . 4 9 1}$, de 13 de outubro de 2017.

67 CtIDH. Caso Gomes Lund y otros (Guerrilha do Araguaia) Vs. Brasil, de 24 de novembro de 2010 .
} 
O trabalho apresentou dois tópicos. No primeiro capítulo, analisou-se, de maneira suscinta, o conceito dos crimes militares. Compreendida a alteraçáo legislativa, no segundo capítulo apresentou-se e conceituou-se o controle de convencionalidade, segundo a baliza da CtIDH, e as modalidades do controle. Ressaltou-se a importância de que os juízes internos façam o controle de convencionalidade difuso, para deixar a Corte Interamericana com aspecto subsidiário.

Com o estudo da alteração legislativa, pode-se observar que os crimes militares se tornaram muito abrangentes, trazendo uma séria insegurança jurídica. Observa-se que, somente pela vigência da Lei 13.491/2017, existe a violação ao princípio do juiz natural, uma vez que o juiz militar não é o juiz natural para julgamento de civis, ainda que estes pratiquem crimes contra militares, conforme amplamente difundido na jurisprudência da Corte Interamericana.

Ao fim do segundo tópico, conclui-se que, apesar do trâmite interno da Lei 13.491/17 ter respeitado todo o ordenamento jurídico brasileiro, a lei rema contra a corrente jurisprudencial e doutrinária dominante na sociedade internacional. Coloca o Brasil em um possível novo julgamento perante a Corte Interamericana de Direitos Humanos, pois, conforme o analisado, é latente a violação ao art. $8^{\circ}$ c/c 1.1 e 2 da Convenção Americana de Direitos Humanos.

Insta salientar que todo o estudo fora realizado sob a égide dos direitos humanos e instrumentos regionais. A insegurança jurídica sustentada é vista pela submissão de civis à Justiça Militar, ainda que exista jurisprudência internacional que determine o não cabimento de julgamento de civis em cortes militares em tempos de paz.

A inconvencionalidade da Lei 13.491/17 se dá, justamente, por atrair mais crimes para a competência militar, bem como por permitir que civis sejam processados perante o colegiado e/ou juiz-auditor na JMU, ainda que o crime não demonstre lesão à organização e ao bom funcionamento da JMU.

\section{REFERÊNCIAS}

ARAS, Vladimir. As novas competências da Justiça Militar após a Lei 13.491/2017. 18 out. 2017. Disponível em: <https://vladimiraras.blog/2017/10/18/as-novas-competencias-da-justica-militar-apos-a-lei-13-4912017/>. Acesso em: 15 out. 2019.

ASSIS, Jorge César de. Curso de Direito Disciplinar Militar: da simples transgressão ao processo administrativo. 3. ed. Curitiba: Juruá, 2012.

BRASIL. Decreto-lei no 2.848, de 7 de dezembro de 1940. Código Penal. Disponível em: <http://www.planalto.gov.br/ccivil_03/decreto-lei/del2848.htm>. Acesso em: 10 abr. 2019.

BRASIL. Decreto-lei no 1.001, de 21 de outubro de 1969. Código Penal Militar. Dis- 
ponível em: <http://www.planalto.gov.br/ccivil_03/decreto-lei/del1001.htm>. Acesso em: 10 abr. 2019.

BRASIL. Decreto-lei no 1.002, de 21 de outubro de 1969. Código de Processo Penal Militar. Disponível em: <http://www.planalto.gov.br/ccivil_03/decreto-lei/Del1002. htm>. Acesso em: 10 abr. 2019.

BRASIL. Lei no 6.880, de 9 de dezembro de 1980. Dispóe sobre o Estatuto dos Militares. Disponível em: <http://www.planalto.gov.br/ccivil_03/LEIS/L6880.htm>. Acesso em: 10 abr. 2019.

BRASIL. Constituição da República Federativa do Brasil de 1988. Disponível em: <http:// www.planalto.gov.br/ccivil_03/constituicao/constituicao.htm>. Acesso em: 12 fev. 2018.

BRASIL. Decreto no 4.346, de 26 de agosto de 2002. Aprova o Regulamento Disciplinar do Exército (R-4) e dá outras providências. Disponível em: <http://www.planalto.gov. br/ccivil_03/ decreto/2002/D4346.htm>. Acesso em: 10 abr. 2019.

BRASIL. Emenda Constitucional no 45, de 30 de dezembro de 2004. Altera dispositivos dos arts. 5०, 36, 52, 92, 93, 95, 98, 99, 102, 103, 104, 105, 107, 109, 111, 112, 114, 115, 125, 126, 127, 128, 129, 134 e 168 da Constituição Federal, e acrescenta os arts. 103-A, 103B, 111-A e 130-A, e dá outras providências. Disponível em: <http://www.planalto.gov. br/ccivil_03/Constituicao/Emendas/Emc/emc45.htm>. Acesso em: 10 abr. 2019.

BRASIL. Superior Tribunal de Justiça (2. Região). Recurso Especial no 2016/0032106o Sáo Paulo. DIREITO PENAL E PROCESSUAL PENAL. RECURSO ESPECIAL. ROUBO, DESACATO E RESISTÊNCIA. APELAÇÃO CRIMINAL. 1. Uma vez interposto o recurso de apelação, o Tribunal, respeitando o contraditório, poderá enfrentar todas as questốes suscitadas, ainda que não decididas na primeira instância, desde que relacionadas ao objeto litigioso recursal, bem como apreciar fundamentos não acolhidos pelo juiz (arts. 10 e 1.1013 , $\$ \$ 1^{\circ}$ e $2^{\circ}$, do Código de Processo Civil, c/c art. $3^{\circ}$ do Código de Processo Penal. 2. A jurisprudência do Superior Tribunal de Justiça afasta a aplicabilidade do princípio da insignificância em crimes cometidos mediante o uso de violência ou grave ameaça, como roubo [...]. $5^{\text {a }}$ turma. Recorrente: Alex Carlos Gomes. Recorrido: Ministério Público do Estado de Sáo Paulo. Relator: Ministro Ribeiro Dantas, 15 de dezembro de 2016. Disponível em: <https://stj.jusbrasil.com.br/ jurisprudencia/424970279/recurso-especial-resp-1640084-sp-2016-0032106-0? ref=juris-tabs>. Acesso em: 25 set. 2018.

BRASIL. Superior Tribunal de Justiça (3a turma). Habeas Corpus no 379.269 Mato Grosso do Sul. VIOLAÇÃO DO ART. 306 DO CÓDIGO DE TRÂNSITO E DOS ARTS. 330 E 331 DO CÓDIGO PENAL. PRINCÍPIO DA CONSUNÇÃO. IMPOSSIBILIDADE. MANUTENÇÃO DA TIPIFICAÇÃO DO CRIME DE DESACATO NO ORDENAMENTO JURİDICO. DIREITOS HUMANOS. PACTO DE SÃO JOSÉ DA COSTA RICA (PSJCR). 1. O Brasil é signatário da Convenção Americana de Direitos Humanos $(\mathrm{CADH})$, denominada Pacto de São José da Costa Rica, sendo promulgada por intermédio do Decreto n. 678/1992, passando, desde então, a figurar com observância obrigatória e integral do Estado [...]. Impetrante: Defensoria Pública do Estado do Mato Grosso do Sul. Impetrado: Tribunal de justiça do Estado do Mato Grosso do Sul. Relator: Ministro 
Reynaldo Soares da Fonseca, 30 de junho de 2017. Disponível em: < https://stj.jusbrasil. com.br/jurisprudencia/474450253/habeas-corpus-hc-379269-ms-2016-0303542-3/inteiro-teor-474450262? ref=juris-tabs>. Acesso em: 28 fev. 2018.

BRASIL. Lei 13.491, de 13 de outubro de 2017. Altera o Decreto-Lei no 1.001, de 21 de outubro de 1969. Código Penal Militar. Disponível em: <http://www.planalto.gov.br/ ccivil_03/_ato2015-2018/2017/lei/113491.htm>. Acesso em: 10 abr. 2019.

COMISSÃO INTERAMERICANA DE DIREITOS HUMANOS (CADH). Pacto de Sáo José da Costa Rica. 22 nov. 1969. Disponível em: <http://www.pge.sp.gov.br/centrodeestudos/ bibliotecavirtual/instrumentos/sanjose.htm>. Acesso em: 14 set. 2018.

COMISSÃO INTERAMERICANA DE DIREITOS HUMANOS (CADH). Regulamento da Comissáo Interamericana de Direitos Humanos. 13 nov. 2009. Disponível em: <http://www.cidh.org/basicos/portugues/u.regulamento.cidh.htm>. Acesso em: 14 set. 2018.

CORTE INTERAMERICANA DE DIREITOS HUMANOS (CtIDH). Caso Cesti Hurtado Vs. Perú. 29 set. 1999. Disponível em: <http://www.corteidh.or.cr/docs/casos/ articulos/seriec_56_esp.pdf >. Acesso em: 23 out. 2018.

CORTE INTERAMERICANA DE DIREITOS HUMANOS (CtIDH). Caso Durand y Ugarte Vs. Perú. 16 ago. 2000. Disponível em: <http://www.corteidh.or.cr/docs/casos/articulos/Seriec_68_esp.pdf>. Acesso em: 14 set. 2018.

CORTE INTERAMERICANA DE DIREITOS HUMANOS (CtIDH). Caso Gómez Palomino vs. Peru. 22 nov. 2005. Disponível em: <http://www.corteidh.or.cr/docs/casos/articulos/seriec_136_esp.pdf>. Acesso em: 23 out. 2018.

CORTE INTERAMERICANA DE DIREITOS HUMANOS (CtIDH). Caso Palamara Iribarne Vs. Chile. 22 nov. 2005. Disponível em: <http://www.corteidh.or.cr/docs/ casos/articulos/seriec_135_esp.pdf >. Acesso em: 23 out. 2018.

CORTE INTERAMERICANA DE DIREITOS HUMANOS (CtIDH). Caso Almonacid Arellano y otros Vs. Chile. 26 set. 2006. Disponível em: <http://www.corteidh. or.cr/docs/ casos/articulos/seriec_154_esp.pdf>. Acesso em: 14 set. 2018.

CORTE INTERAMERICANA DE DIREITOS HUMANOS (CtIDH). Caso Trabajadores Cesados del Congreso vs Peru. 24 nov. 2006. Disponível em: <http://www. corteidh.or.cr/docs/ casos/articulos/seriec_158_esp.pdf>. Acesso em: 14 set. 2018.

CORTE INTERAMERICANA DE DIREITOS HUMANOS (CtIDH). Caso La Cantuta Vs. Perú. 29 nov. 2006. Disponível em: <http://www.corteidh.or.cr/docs/casos/articulos/seriec_162_esp.pdf>. Acesso em: 14 set. 2018.

CORTE INTERAMERICANA DE DIREITOS HUMANOS (CtIDH). Caso Boyce y otros vs Barbados. 2 nov. 2007. Disponível em: <http://www.corteidh.or.cr/docs/casos/ articulos/seriec_169_esp.pdf>. Acesso em: 14 set. 2018. 
CORTE INTERAMERICANA DE DIREITOS HUMANOS (CtIDH). Caso Gomes Lund y otros (Guerrilha do Araguaia) Vs. Brasil. 24 nov. 2010. Disponível em: <http:// www.corteidh.or.cr/docs/casos/articulos/seriec_219_por.pdf>. Acesso em: 14 set. 2018.

CORTE INTERAMERICANA DE DIREITOS HUMANOS (CtIDH). Caso Liakat Ali Alibux vs Suriname. 30 jan. 2014. Disponível em: <https://www.cnj.jus.br/wp-content/uploads/2016/ 04/76dc0db310925e305df1def0e12c9ee7.pdf>. Acesso em: 14 set. 2018.

CORTE INTERAMERICANA DE DIREITOS HUMANOS (CtIDH). Caso Argüelles y otros Vs. Argentina. 20 nov. 2014. Disponível em: <http://www.corteidh.or.cr/ docs/casos/articulos/seriec_288_esp.pdf>. Acesso em: 23 out. 2018.

CORTE INTERAMERICANA DE DIREITOS HUMANOS (CtIDH). Relatório Anual da Corte Interamericana de Direitos Humanos. San José: A Corte, 2018. Disponível em: <http://www.corteidh.or.cr/sitios/informes/docs/POR/por_2017.pdf>. Acesso em: 23 out. 2018.

GOMES, Luiz Flávio. Comentários à Convençáo Americana sobre Direitos Humanos: pacto de San José da Costa Rica. 4. ed. São Paulo: Editora Revista dos Tribunais, 2013.

LEIRNER, Piero de Camargo. Meia-volta volver: um estudo antropológico sobre a hierarquia militar. Rio de Janeiro: Editora FGV, 1997.

MAZZUOLI, Valério de Oliveira. $\mathbf{O}$ controle jurisdicional da convencionalidade das leis. 3. ed. São Paulo: Editora Revista dos Tribunais, 2013. v. 4.

NEVES, Cícero Robson Coimbra. Manual de Direito Penal Militar. 2. ed. São Paulo: Saraiva, 2012.

PAIVA, Caio; HEEMANN, Thimotie Aragon. Jurisprudência internacional de direitos humanos. Manaus: Dizer o Direito, 2015.

REY, Sebastián A. Manual de Derecho Internacional de Los Derechos Humanos: Parte General. 1. ed. Buenos Aires: Ad-Hoc, 2016.

ROTH, Ronaldo João. Justiça Militar e as peculiaridades do Juiz Militar na atuaçáo jurisdicional. São Paulo: Juarez de Oliveira, 2003.

SAGÜÉS, Néstor Pedro. Obligaciones internacionales y control de convencionalidad. Estudios Constitucionales, v. 8, n. 1, p. 271-292, 2011. Disponível em: < http://www. corteidh.or.cr/ tablas/28053-11.pdf>. Acesso em: 15 fev. 2018.

SILVESTRE, Lucas Alexandre Cardoso. Ontologia dos Militares: a organização com base na hierarquia e na disciplina. Revista Direito Militar, Florianópolis, n. 121, set./dez. 2016. Disponível em:_<http://files.revista-academica-online.webnode.com/ 200000221-4b5564c51f/ Materia_1_Ten_Lucas\%20Alexandre20170111_16151032. pdf >. Acesso em: 21 jun. 2018. 